\title{
Effects of Frequency of "Extreme" Temperature Highs on Development of Soybean Rust
}

\author{
M. R. Bonde, S. E. Nester, and D. K. Berner
}

United States Department of Agriculture-Agricultural Research Service, Foreign Disease-Weed Science Research Unit, 1301 Ditto Ave., Fort Detrick, Frederick, MD 21702-5023. Accepted for publication 6 February 2013.

\section{ABSTRACT}

Bonde, M. R., Nester, S. E. , and Berner, D. K. 2013. Effects of frequency of "extreme" temperature highs on development of soybean rust. Phytopathology 103:708-716.

Previously, we hypothesized that summer "extreme" diurnal temperature highs in the southeastern United States were responsible for the yearly absence or delay of soybean rust development until fall. Utilizing temperature-controlled growth chambers, a diurnal temperature pattern of $33^{\circ} \mathrm{C}$ high and $20^{\circ} \mathrm{C}$ low reduced urediniospore production by $81 \%$. However, that study did not consider the influence of frequency of extreme temperatures on soybean rust. We now report that a temperature high of $35^{\circ} \mathrm{C}$ for $1 \mathrm{~h}$ on three consecutive days, initiated 15 days after inoculation, when lesions had formed, reduced urediniospore production by $50 \%$ and required 9 to 12 days for sporulation to resume once the extreme temperature highs ceased. Furthermore, three consecutive days in which the temperature high was $37^{\circ} \mathrm{C}$, beginning immediately after inoculation and subsequent dew period, reduced lesion numbers by $60 \%$. The combined effects of reduced numbers of lesions and urediniospores per lesion caused by extreme temperature highs can account for observed absence or delay of soybean rust development in the southeastern United States until fall. A comparison of frequency of extreme temperature highs with numbers of counties reporting presence of soybean rust from 2005 to 2012 verified that extreme temperature highs may be largely responsible for absence or delay of soybean rust development. This is the first report showing the effect of frequency of extreme temperature highs on development of soybean rust. Because the south-to-north progression of soybean rust is required for the disease to occur in the major soybean-production regions of the United States, temperatures in the southeastern United States have a major effect on the entire U.S. soybean industry.
Soybean rust, caused by Phakopsora pachyrhizi Syd. \& P. Syd., was discovered in Japan in 1902 (12) and, since then, has spread to all major soybean-producing regions of the world $(8,16$, $22,23,24)$. The discovery of the disease in the southeastern United States in November 2004 (24) generated considerable national concern because of the importance of soybean production to the economy of the United States in conjunction with extensive reports of high disease losses in Africa (16), Asia (8), and South America $(22,23)$. As a result of the possible threat of soybean rust to U.S. agriculture, a massive effort was initiated to gain information about the disease and prevent potential loss $(3,9,14$, $15,17,28)$. An example of the effort was creation of the United States Department of Agriculture (USDA) Pest Information Platform for Extension and Education (http://sbrusa.net).

P. pachyrhizi is an obligate fungal plant pathogen that survives through the winter, at least in small pockets, on the leguminous weed kudzu in the southeastern United States $(6,7)$. From these isolated areas, and those in Mexico and the Caribbean region, inoculum is provided to initiate the disease on soybean in the southeastern United States during spring (13). Because the pathogen apparently does not survive through winter in midwestern and northern regions of the United States, where most soybean crops are grown, the potential yearly south-to-north disease progression during the cropping season has major implications for the entire U.S. soybean industry.

Corresponding author: M. R. Bonde;

E-mail address: Morris.bonde@ars.usda.gov

http://dx.doi.org/10.1094/PHYTO-09-12-0250-R

This article is in the public domain and not copyrightable. It may be freely reprinted with customary crediting of the source. The American Phytopathological Society, 2013.
Temperature and moisture are recognized as the two most important environmental factors determining the rate at which soybean rust develops $(9,19)$. Moisture has been described as the driving force for the disease (8). Whereas rain can provide the necessary moisture, dew probably is the more important source of free water (19). Dew periods are believed to be of sufficient duration and temperature to promote soybean rust development throughout most U.S. soybean-producing regions during most, if not all, of the growing season (19).

However, in spite of the fact that $P$. pachyrhizi can survive winters in the southeastern United States and areas further to the south, and moisture conditions apparently are conducive for development of soybean rust, disease severity generally has remained at low levels $(10,14)$. When disease severity did increase, generally it was late in the cropping season, and had little opportunity to significantly affect crop yield (14).

In a recent report, we suggested that the observed absence or delay of soybean rust development was due, in part, to "extreme" diurnal temperature highs, lasting from one to a few hours per day, during summer months in the southeastern United States $(2,5)$. We demonstrated that diurnal temperature highs of 29,33 , or $37^{\circ} \mathrm{C}$ for $1 \mathrm{~h}$ per day reduced urediniospore production to 39 , 19 , and $0 \%$, respectively, compared with urediniospore production under optimum temperature conditions $(2,5)$. No lesions were produced with a diurnal temperature high of $37^{\circ} \mathrm{C}$. The term "extreme" was used to describe these temperature highs, even though they were not particularly high and apparently were common under field conditions in the southeastern United States. Temperature extremes, even for brief periods (e.g., $1 \mathrm{~h}$ ), have a greater effect on disease than temperature means (26). Two days can have the same mean temperature but be very different because of different temperature amplitudes. The negative effects on disease caused by a few days with extreme temperature highs 
cannot be compensated for by many days with favorable temperatures for disease. Although we showed that a prolonged period with extreme temperature highs greatly reduce disease development, under normal field conditions temperature patterns never are constant.

The objective of this study was to determine the effect of frequency of specific extreme temperature highs on lesion and urediniospore production. Our hypothesis was that extreme temperature highs occur often enough to account for the observed absence or delay of soybean rust development in the southeastern United States. Two scenarios would be tested: (i) infected soybean plants would be subjected to extreme temperature highs immediately after inoculation and a subsequent dew period, before the pathogen was fully established in the host tissue; and (ii) inoculated plants would be subjected to extreme temperature highs beginning 15 days after inoculation, when the pathogen was established in soybean host tissue and lesions formed. The number of consecutive days with an extreme temperature high would vary from zero to nine. Following each series of extreme temperature highs, the temperature pattern would be changed to an optimum diurnal temperature pattern for disease development. Published temperature and soybean rust incidence records, the latter from the USDA Pipe website (www.sbrusa.net), expressed as numbers of counties reporting soybean rust, would be examined to determine whether there is a relationship between frequency of extreme temperature highs and low soybean rust incidence.

\section{MATERIALS AND METHODS}

Pathogen and host. $P$. pachyrhizi isolate Alabama 04-1, from Mobile County, AL, collected in 2004, was used throughout the study. The isolate was purified by serial passage through several rounds of single pustules on the soybean 'Williams 82' (4). Extensive studies conducted at the Foreign Disease-Weed Science Research Unit (FDWSRU) have indicated that this isolate was typical of all U.S. isolates in the Unit's soybean rust collection with respect to aggressiveness and response to environmental conditions (M. R. Bonde, S. E. Nester, and D. K. Berner, unpublished data).

Soybean Williams 82 plants were grown in 10.2-cm-diameter clay pots for 30 days, then transferred to 20 -cm-diameter plastic pots. After an additional 20 days, all leaves except four trifoliate leaves (leaves 6 to 9) per plant were removed. Pruning allowed the remaining leaves on the plants to be under essentially identical environmental conditions later, when in dew or growth chambers. Potting soil used throughout the study was the standard soil mix used at FDWSRU (5). Prior to inoculation, plants were given $16 \mathrm{~h}$ of supplemental lighting per day in the greenhouse and fertilized with 14-14-14 Osmocote (Scotts Miracle-Gro Company, Marysville, $\mathrm{OH})$.

Following pruning, plants at vegetative growth stage V-6 to V-9 were inoculated by dipping each remaining trifoliate leaf individually into a urediniospore suspension $\left(3 \times 10^{4}\right.$ urediniospores $/ \mathrm{ml}$ ) in aqueous $0.04 \%$ Tween 20 in a 2-liter beaker. Tween 20 was used as a wetting agent to facilitate uniform distribution of inoculum on leaves.

Diurnal temperature patterns and conditions during experiments. The extreme temperature highs to be tested were selected based on results of the previous study (5). Both 35 and $37^{\circ} \mathrm{C}$ are typical temperature highs occurring during growing seasons, particularly during the months of July and August (Southeast Regional Climate Center website; www.sercc.com). For experiments, each growth chamber was programmed to operate with a diurnal temperature high of either 35 or $37^{\circ} \mathrm{C}$, depending on the experiment, and diurnal low $13^{\circ} \mathrm{C}$ below the high. The difference between the diurnal high and low was based on average weather data from five weather stations, one in each of the five southeastern states, from April through November, over a 24- to 56-year period (5). Remarkably, the average difference was nearly the same for all five states and months, and equaled $12.8 \pm$ $1.6^{\circ} \mathrm{C}(5)$.

In each growth chamber, the temperature was gradually raised from a temperature low at 6:00 to 7:00 a.m. to a high at 4:00 to 5:00 p.m., with 1-h durations at the two temperature extremes (Fig. 1). Day length was $14 \mathrm{~h}$ with fluorescent and incandescent lights. Twilight was 6:30 to 7:00 a.m. and dusk 9:00 to 9:30 p.m., each with only incandescent lights. The duration for diurnal highs and lows was based on the average duration during summer months over a 3 -year period in a field plot in Griffin, GA (5). Using the same shape for diurnal temperature patterns throughout this and the previous study simplified analyses of experimental results. More important, the patterns represented actual temperature conditions, along with lighting conditions, in the field.

Plants were automatically watered twice per day from drip tubes, such that the soil in each pot reached saturation and subsequently partially dried. They were examined regularly to ensure that none of the plants became stressed from over or under watering. A Hobo H8 Pro Series logger (Onset Computer Corporation, Pocasset, MA), with an accuracy of $\pm 3.0 \%$, based on information from the manufacturer, continuously monitored the relative humidity (RH) in each chamber. The $\mathrm{RH}$ varied between $\approx 45$ and $92 \%$, depending on time of day and diurnal temperature pattern. Results from an ancillary study in which plants were maintained in growth chambers at 20 or $90 \% \mathrm{RH}, 29^{\circ} \mathrm{C}$ day and $16^{\circ} \mathrm{C}$ night for the entire post-inoculation period, showed that $\mathrm{RH}$ had no significant effect on lesion numbers or urediniospore production if plants never became stressed by over or under watering (5). Results from another ancillary study showed that leaf and air temperatures in growth chambers were always nearly identical. Therefore, temperatures experienced by the pathogen can be assumed to be equal to air temperatures reported in this article.

Determination of effects of frequency of extreme temperature highs beginning immediately after inoculation and dew period. Inoculated plants were incubated overnight in a dew chamber at $20^{\circ} \mathrm{C}$ to initiate infection and, the next day, three plants were distributed to each of four temperature-controlled growth chambers. Three chambers were programmed to operate with a $37^{\circ} \mathrm{C}$ high and $24^{\circ} \mathrm{C}$ low diurnal temperature pattern (Fig. $1)$. Three days after inoculation, one growth chamber was re-

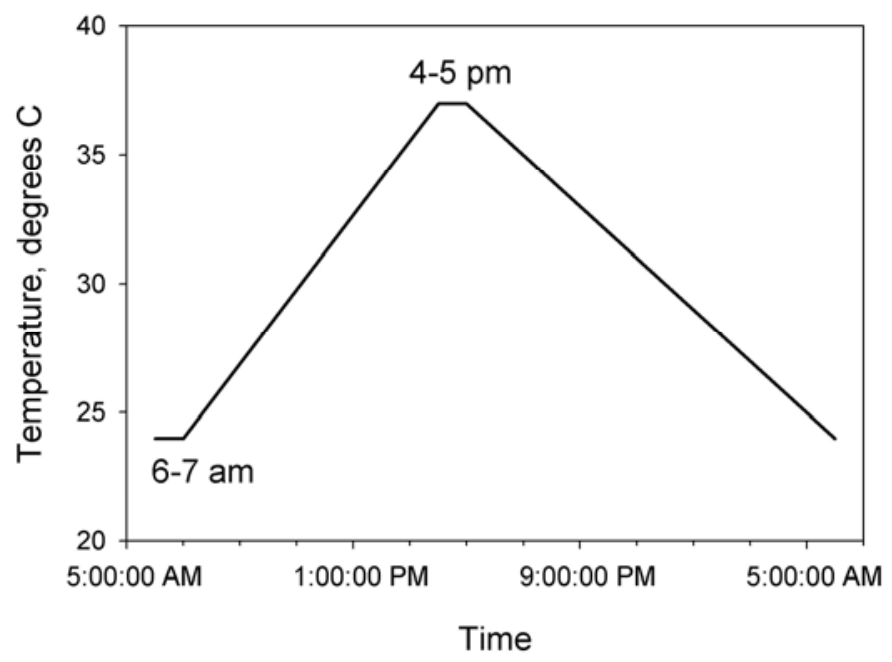

Fig. 1. Diurnal temperature profile in which the temperature gradually rose from a low at 6:00 to 7:00 a.m., reached a high at 4:00 to 5:00 p.m., and then gradually returned to the low at 6:00 to 7:00 a.m. Lighting simulated day, dusk, night, and dawn as previously described (5). 
programmed to operate at $25^{\circ} \mathrm{C}$ high and $12^{\circ} \mathrm{C}$ low (optimum for disease development) (5). The second and third chambers were reprogrammed to operate at $25^{\circ} \mathrm{C}$ high and $12^{\circ} \mathrm{C}$ low 6 and 9 days after inoculation, respectively. A fourth chamber operated the same as the other three chambers, except that it was programmed for a $25^{\circ} \mathrm{C}$ high and $12^{\circ} \mathrm{C}$ low for the entire time to serve as the control. Beginning 12 days after inoculation, urediniospores were collected from each plant by means of a vacuum-spore harvester at 3-day intervals and counted as previously described (5).

At the end of the experiment, 33 days after inoculation, the number of lesions on each leaf and corresponding leaf area were determined as previously described (5) and data used to calculate lesions per square centimeter of leaf area for the leaf and plant. Based on leaf drop data, the number of lesions contributing to urediniospore production for each plant-collection date-treatment was calculated. The number of urediniospores collected per plant on each collection date was divided by the corresponding number of lesions on the plant to determine the number of urediniospores produced per lesion per collection date per plant. These were totaled to determine total number of urediniospores produced per lesion during the course of the experiment for each plant. The experiment was conducted three times and data combined for analyses. Each specific treatment was conducted in a different chamber among experiments.

Determination of effects of frequency of extreme diurnal temperature highs beginning after lesion formation. Soybean plants were inoculated and incubated for $16 \mathrm{~h}$ in a dew chamber as described above. After the dew period, three plants were distributed to each of four growth chambers programmed to operate at $25^{\circ} \mathrm{C}$ high and $12^{\circ} \mathrm{C}$ low, optimum for disease development (5). After 15 days, three of the growth chambers were reprogrammed to operate at $35^{\circ} \mathrm{C}$ high and $22^{\circ} \mathrm{C}$ low (shape of the temperature pattern similar to that in Figure 1). At 3, 6, or 9 days after the temperature profiles were raised, one chamber on each date was reprogrammed to operate with a $25^{\circ} \mathrm{C}$ high and $12^{\circ} \mathrm{C}$ low diurnal temperature cycle. Thus, inoculated plants were subjected to a $35^{\circ} \mathrm{C}$ diurnal temperature high for zero, three, six, or nine consecutive days, before return to the optimum temperature cycle conditions for the remainder of the experiment. Urediniospores were collected at 3-day intervals, as described above, from each plant beginning 12 days after inoculation. Position and date of each leaf that dropped from plants was recorded as described above.

At the end of the experiment, 33 days after inoculation, for each treatment, the number of lesions per square centimeter of leaf area, number of urediniospores produced per lesion per collection date, and total cumulative number of urediniospores produced per lesion over the course of the experiment were determined as described above. The experiment was conducted three times and data combined for analyses as above. Each specific treatment was conducted in a different chamber among experiments.

Analyses of data from growth chambers. All analyses were done with Statistical Analysis System (SAS) version 9.2 software.

TABLE 1. Frequency of days in which the diurnal temperature high reached or exceeded $35^{\circ} \mathrm{C}$ in specific states during the years 2005 to 2012 based on data from the National Climatic Data Center ${ }^{\mathrm{a}}$

\begin{tabular}{|c|c|c|c|c|c|c|c|}
\hline \multirow[b]{2}{*}{ Year } & \multicolumn{7}{|c|}{ State, city, location } \\
\hline & $\begin{array}{c}\text { Alabama } \\
\text { Montgomery } \\
\text { Regional Airport }\end{array}$ & $\begin{array}{c}\text { Florida } \\
\text { Jacksonville } \\
\text { International Airport }\end{array}$ & $\begin{array}{c}\text { Mississippi } \\
\text { Jackson International } \\
\text { Airport }\end{array}$ & $\begin{array}{c}\text { Georgia Middle } \\
\text { Georgia Regional } \\
\text { Airport (Macon) }\end{array}$ & $\begin{array}{c}\text { Illinois Greater } \\
\text { Peoria Regional } \\
\text { Airport }\end{array}$ & $\begin{array}{c}\text { Iowa } \\
\text { Des Moines } \\
\text { International Airport }\end{array}$ & $\begin{array}{c}\text { Nebraska } \\
\text { Lincoln } \\
\text { Municipal Airport }\end{array}$ \\
\hline 2005 & 0 & 0 & 0 & 0 & 0 & 0 & 0 \\
\hline 2006 & 0 & 0 & 0 & 0 & 0 & 0 & 0 \\
\hline 2007 & 0 & 0 & 0 & 0 & 0 & 0 & 0 \\
\hline 2011 & 0 & 0 & 0 & 0 & 0 & 0 & 0 \\
\hline 2012 & 0 & 0 & 0 & 0 & 0 & 0 & 0 \\
\hline \multicolumn{8}{|l|}{ May } \\
\hline 2005 & 0 & 0 & 0 & 0 & 0 & 0 & 0 \\
\hline 2006 & 0 & 1,2 & 0 & 1,2 & 0 & 0 & 0 \\
\hline 2007 & 0 & 0 & 0 & 0 & 0 & 0 & 0 \\
\hline \multicolumn{8}{|l|}{ June } \\
\hline 2005 & 1 & 2 & 1 & 1 & $1,4,1$ & 1 & $3,2,1$ \\
\hline 2006 & $2,2,5$ & 3 & $3,1,1,1$ & $2,4,1$ & 0 & 0 & $1,1,3$ \\
\hline 2007 & $7,2,1,3,1,4$ & 2 & $7,1,3,3$ & $3,3,2$ & 0 & 0 & 0 \\
\hline 2008 & $7,1,2,3$ & 1 & 1 & $7,1,4$ & 0 & 0 & 0 \\
\hline 2009 & 15 & $1,1,4,2,1$ & 19 & 6,8 & 1 & 1 & 1 \\
\hline 2010 & 18 & 10,4 & $3,1,3,5$ & $5,1,2,5,1$ & 0 & 0 & 1 \\
\hline 2011 & $8,8,4,2$ & $2,5,5,1$ & $8,11,2$ & $19,1,4,2,1$ & 0 & 1,2 & 3,2 \\
\hline 2012 & $1,2,4$ & 2 & 13 & 1,4 & 2 & 1,2 & $1,1,2$ \\
\hline \multicolumn{8}{|l|}{ July } \\
\hline 2005 & 1,4 & 2,2 & 1,5 & $3,1,9$ & $1,2,2$ & 1,3 & $1,2,3,1,4$ \\
\hline 2006 & $6,13,3$ & $1,2,1,1$ & $2,7,2,1$ & $5,13,2$ & 3 & $1,2,1,3$ & $5,1,2,5$ \\
\hline 2007 & 2,3 & 4,3 & 0 & 1,1 & 0 & 1,1 & $3,5,2$ \\
\hline 2008 & $3,4,1$ & 1 & $1,1,1,6,4$ & 3,1 & 0 & 0 & $1,1,1,1$ \\
\hline
\end{tabular}

\footnotetext{
a Numbers indicate the number of days in continuous sequence in which the temperature high was $\geq 35^{\circ} \mathrm{C}$. If the sequence spanned 2 months, it was placed in the month with the greater number of days reaching $\geq 35^{\circ} \mathrm{C}$.
} 
The experimental design was repeated measures in time (days of observation after inoculation) for a factorial set of treatments (temperature and number consecutive days with extreme temperature high) laid out in randomized blocks, three separate runs of the experiment in time, in four environmental growth chambers. Sampling units within each chamber and run were three plants. For the variable of urediniospores per lesion, areas under spore-producing curves were produced over the 12, 15, 18, $21,23,27,30$, and 33 days of observation. This was done for each temperature $\left(37\right.$ or $\left.35^{\circ} \mathrm{C}\right)$ and number days of extreme temperature high (i.e., $n=0,3,6$, and 9 days) for each plant in each experiment (run) in each environmental growth chamber. The areas under the curves for each temperature were calculated using the lag function in SAS: area = ([spores per lesion + $\operatorname{lag}($ spores per lesion)]/2) $\times$ (observation day-lag[observation day]). The sums of these areas over the days of observation were then calculated for each plant with the SUMMARY procedure of SAS, and the mean areas across plants were generated for each experiment (run) and environmental chamber with the MEANS procedure of SAS. An analysis of covariance was then performed on these areas with the MIXED procedure of SAS. Temperature $\left(37\right.$ or $35^{\circ} \mathrm{C}$ ) was a fixed classification variable and number of days of extreme temperature high within temperatures was a continuous covariable. Experiment (run) was a random effect in the model. From this analysis, linear regressions within each temperature were generated for areas under the spore-producing curves. Means and standard errors across plants, experiments, and environmental chambers for each day of extreme temperature high within each temperature were calculated for each observation day. These means were plotted against observation days.

Means for lesions produced per centimeter of leaf area and total spores produced were generated for each number of days with extreme temperature high and experiment (run) within each temperature. Linear regressions within each temperature were generated for these two variables based on these means. Nonlinear exponential decay models, a reasonable, biologically explicable alternative to a linear model, fit the data less well than linear models based on comparison of Akaike's information criteria (AIC) (1). These analyses were conducted as described for spore-producing areas and analyses of covariance with the MIXED procedure of SAS.

Frequencies of extreme temperature highs in the field. In order to relate lesion formation and urediniospore production in growth chambers to actual temperature conditions in the field, the frequency of days in which the temperature reached or exceeded 37 or $35^{\circ} \mathrm{C}$ was determined for one field location in each of seven states from 2005 to 2012, the 8 years immediately following discovery of soybean rust in the southeastern United States. Data from the National Climate Data Center included daily temperature highs at one weather station for each of the three midwestern states of Illinois, Iowa, and Nebraska, and for each of the southeastern states of Alabama, Florida, Mississippi, and Georgia (Tables 1 and 2).

Field incidence of disease from 2005 to 2012. Data for this portion of the study was based on cumulative numbers of counties

TABLE 1. (continued from preceding page)

\begin{tabular}{|c|c|c|c|c|c|c|c|}
\hline \multirow[b]{2}{*}{ Year } & \multicolumn{7}{|c|}{ State, city, location } \\
\hline & $\begin{array}{c}\text { Alabama } \\
\text { Montgomery } \\
\text { Regional Airport }\end{array}$ & $\begin{array}{c}\text { Florida } \\
\text { Jacksonville } \\
\text { International Airport }\end{array}$ & $\begin{array}{l}\text { Mississippi } \\
\text { Jackson International } \\
\text { Airport }\end{array}$ & $\begin{array}{c}\text { Georgia Middle } \\
\text { Georgia Regional } \\
\text { Airport (Macon) }\end{array}$ & $\begin{array}{c}\text { Illinois Greater } \\
\text { Peoria Regional } \\
\text { Airport }\end{array}$ & $\begin{array}{c}\text { Iowa } \\
\text { Des Moines } \\
\text { International Airport }\end{array}$ & $\begin{array}{c}\text { Nebraska } \\
\text { Lincoln } \\
\text { Municipal Airport }\end{array}$ \\
\hline 2011 & $3,4,3$ & $1,1,5,2$ & $6,9,2,1$ & $3,1,1,4,7,2$ & 5,1 & 4,1 & $1,6,2,2$ \\
\hline 2012 & $4,2,3,9$ & $1,3,3,1$ & $1,1,5$ & $3,3,5,3$ & $6,1,3,1,1,1$ & $7,6,6,2$ & $5,15,7$ \\
\hline \multicolumn{8}{|c|}{ August } \\
\hline 2005 & 4,1 & 1,3 & $4,10,1$ & 1,6 & 1,1 & 1,1 & 2,2 \\
\hline 2006 & $9,1,2,3,3$ & $4,4,1,1,1$ & $9,8,1,2$ & $4,6,1,3$ & 4 & 0 & $1,1,1$ \\
\hline 2007 & 24 & $7,1,1$ & 23,2 & 14,3 & 1,1 & 0 & $1,6,2,1$ \\
\hline 2008 & 6 & 2 & 1,1 & 1,4 & 0 & 1 & 2,1 \\
\hline 2009 & 1 & 2 & 1 & 1,5 & 0 & 1 & 2,1 \\
\hline 2010 & $15,1,1,8$ & $2,7,1$ & $7,6,2,3$ & $4,7,3,1$ & 0 & 1 & $6,1,1$ \\
\hline 2011 & $5,4,1,1,17$ & $3,7,1,1,4$ & $14,1,17$ & $13,3,9$ & 1,1 & 2 & 3,1 \\
\hline 2012 & $2,1,1$ & 1 & $1,1,1$ & 2 & 1,1 & $3,1,2,2$ & 3,6 \\
\hline \multicolumn{8}{|c|}{ September } \\
\hline 2005 & 2,4 & 1 & 4 & 7 & 1 & 0 & 1 \\
\hline 2006 & 0 & 0 & 0 & 0 & 0 & 0 & 0 \\
\hline 2007 & 2 & 0 & 0 & 0 & 0 & 0 & 0 \\
\hline 2008 & 0 & 0 & 0 & 0 & 0 & 0 & 0 \\
\hline 2009 & 0 & 0 & 0 & 0 & 0 & 0 & 0 \\
\hline 2010 & $1,6,1,9$ & 3 & $3,8,2$ & $1,3,5,1$ & 0 & 0 & 0 \\
\hline 2011 & 0 & 0 & 0 & 3,1 & 3 & 1 & 1 \\
\hline 2012 & 0 & 0 & 3 & 0 & 0 & 1 & 1,1 \\
\hline \multicolumn{8}{|c|}{ October } \\
\hline 2005 & 0 & 0 & 0 & 0 & 0 & 0 & 0 \\
\hline 2006 & 0 & 0 & 1 & 0 & 0 & 0 & 0 \\
\hline 2007 & 0 & 0 & 0 & 0 & 0 & 0 & 0 \\
\hline 2008 & 0 & 0 & 0 & 0 & 0 & 0 & 0 \\
\hline 2009 & 0 & 0 & 0 & 0 & 0 & 0 & 0 \\
\hline 2010 & 0 & 0 & 0 & 0 & 0 & 0 & 0 \\
\hline 2011 & 0 & 0 & 0 & 0 & 0 & 0 & 0 \\
\hline 2012 & 0 & 0 & 0 & 0 & 0 & 0 & 0 \\
\hline \multicolumn{8}{|c|}{ November } \\
\hline 2005 & 0 & 0 & 0 & 0 & 0 & 0 & 0 \\
\hline 2006 & 0 & 0 & 0 & 0 & 0 & 0 & 0 \\
\hline 2007 & 0 & 0 & 0 & 0 & 0 & 0 & 0 \\
\hline 2008 & 0 & 0 & 0 & 0 & 0 & 0 & 0 \\
\hline 2009 & 0 & 0 & 0 & 0 & 0 & 0 & 0 \\
\hline 2010 & 0 & 0 & 0 & 0 & 0 & 0 & 0 \\
\hline 2011 & 0 & 0 & 0 & 0 & 0 & 0 & 0 \\
\hline 2012 & 0 & 0 & 0 & 0 & 0 & 0 & 0 \\
\hline
\end{tabular}


by 21 November of each year reporting the presence of soybean rust on the USDA Public PIPE website (www.sbrusa.net). By that date, soybean rust spread had been completed and reported. The number of counties reporting soybean rust can be considered a reflection of cumulative disease incidences for that year. Based on information for the representative year 2006, data for the website was derived from a network of soybean rust sentinel plots established in 35 U.S. states and five Canadian provinces $(11,15)$. The vast majority of the plots $(n=650)$ were planted to soybean, 64 had established stands of kudzu, and 30 were planted to non-soybean leguminous crops $(11,15)$. In most instances, soybean plots had two cultivars, one from the maturity group typical for the area and the second a cultivar from an earlier-maturing group. Usually for each sampling, 100 leaves were collected from the lower to middle canopy of each cultivar or kudzu on a weekly schedule. At some sentinel plots, the leaves were examined while in the field by trained plant pathologists whereas, in the majority of instances, leaves were collected and incubated in a moist environment for 24 to $48 \mathrm{~h}$ and examined microscopically in a laboratory $(11,15)$. The sentinel plot network was augmented by mobile scouting units which included plant pathologists and agricultural extension specialists. For example, in 2006, there were 17,797 observations submitted to the national soybean rust database from a total of $\approx 2,000$ geographic locations throughout the United States and southern Canada. The survey, beginning in 2005, is probably one of the most extensive surveys ever conducted (M. R. Bonde, personal observation).

\section{RESULTS}

Effects of frequency of extreme temperature highs beginning immediately after inoculation and dew period. In this set of experiments, extreme temperature highs were initiated immediately after initiation of infection in soybean. The results showed that, with as few as three consecutive days in which the temperature reached $37^{\circ} \mathrm{C}$ for $1 \mathrm{~h}$, there was a significant $(P=0.006)$ decrease in number of lesions from 22 to 12 lesions $/ \mathrm{cm}^{2}$ of leaf area (Fig. 2A). The cumulative number of urediniospores produced per plant over 33 days following inoculation was reduced from $76 \times 10^{3}$ to $32 \times 10^{3}$ (Fig. 2B) $(P=0.002)$ and urediniospores per lesion from $2.8 \times 10^{3}$ to $2.2 \times 10^{3}$ (Fig. $\left.2 \mathrm{C}\right)(P=$ not significant). It was apparent that most of the reduction in cumulative numbers of urediniospores produced was a direct result of fewer lesions produced when there were three consecutive days in which the temperature reached $37^{\circ} \mathrm{C}$ for $1 \mathrm{~h}$ beginning immediately after inoculation and a dew period (Fig. 2A). With six or nine consecutive days, there was little or no further reduction in total cumulative numbers of urediniospores produced over the course of the experiment (Fig. 2B).

Urediniospore production began to resume by 9 to 12 days after cessation of the extreme temperature highs (Fig. 3). Although urediniospore production per lesion following cessation of the temperature extreme eventually reached that of the control (Fig. 3 ), the cumulative number of urediniospores per plant produced during the experiment never reached that of the control with no extreme temperature high (Fig. 2B).

TABLE 2. Frequency of days in which the diurnal temperature high reached or exceeded $37^{\circ} \mathrm{C}$ in specific states during the years 2005 to 2012 based on temperature data from the National Climatic Data Center ${ }^{\mathrm{a}}$

\begin{tabular}{|c|c|c|c|c|c|c|c|}
\hline \multirow[b]{2}{*}{ Year } & \multicolumn{7}{|c|}{ State, city, location } \\
\hline & $\begin{array}{c}\text { Alabama } \\
\text { Montgomery } \\
\text { Regional Airport }\end{array}$ & $\begin{array}{c}\text { Florida } \\
\text { Jacksonville } \\
\text { International Airport }\end{array}$ & $\begin{array}{l}\text { Mississippi } \\
\text { Jackson International } \\
\text { t } \quad \text { Airport }\end{array}$ & $\begin{array}{l}\text { Georgia Middle } \\
\text { Georgia Regional } \\
\text { Airport (Macon) }\end{array}$ & $\begin{array}{l}\text { Illinois Greater } \\
\text { Peoria Regional } \\
\text { Airport }\end{array}$ & $\begin{array}{c}\text { Iowa } \\
\text { Des Moines } \\
\text { International Airport }\end{array}$ & $\begin{array}{c}\text { Nebraska } \\
\text { Lincoln } \\
\text { Municipal Airport }\end{array}$ \\
\hline 2005 & 0 & 0 & 0 & 0 & 0 & 0 & 0 \\
\hline 2006 & 0 & 0 & 0 & 0 & 0 & 0 & 0 \\
\hline 2007 & 0 & 0 & 0 & 0 & 0 & 0 & 0 \\
\hline 2011 & 0 & 0 & 0 & 0 & 0 & 0 & 0 \\
\hline 2012 & 0 & 0 & 0 & 0 & 0 & 0 & 0 \\
\hline \multicolumn{8}{|l|}{ May } \\
\hline 2005 & 0 & 0 & 0 & 0 & 0 & 0 & 0 \\
\hline 2006 & 0 & 0 & 0 & 0 & 0 & 0 & 0 \\
\hline 2007 & 0 & 0 & 0 & 0 & 0 & 0 & 0 \\
\hline \multicolumn{8}{|l|}{ June } \\
\hline 2005 & 0 & 0 & 0 & 0 & 0 & 0 & 0 \\
\hline 2006 & 2 & 0 & 0 & 3 & 0 & 0 & 1 \\
\hline 2007 & 1,3 & 0 & 0 & 0 & 0 & 0 & 0 \\
\hline 2008 & 0 & 0 & 0 & 2 & 0 & 0 & 0 \\
\hline 2009 & 1,1 & 0 & 2,3 & 0 & 0 & 0 & 1 \\
\hline 2010 & $2,1,1$ & 1,3 & 0 & 2 & 0 & 0 & 0 \\
\hline 2011 & $3,2,1,3$ & 0 & $4,1,1,1,2$ & $3,2,3$ & 0 & 0 & 1,2 \\
\hline 2012 & 3 & 0 & 1,3 & 4 & 1 & 1 & 1 \\
\hline \multicolumn{8}{|l|}{ July } \\
\hline 2005 & 0 & 0 & 0 & 1 & 2 & 0 & $1,1,4$ \\
\hline 2006 & $3,1,2$ & 0 & 3 & $1,2,6$ & 0 & 1,1 & $1,1,1,1,4$ \\
\hline 2007 & 1 & 0 & 0 & 0 & 0 & 0 & 1,2 \\
\hline 2008 & 0 & 0 & 2,3 & 1 & 0 & 0 & 0 \\
\hline
\end{tabular}

\footnotetext{
${ }^{a}$ Numbers indicate the number of days in continuous sequence in which the temperature high was $\geq 37^{\circ} \mathrm{C}$. If the sequence spanned 2 months, the sequence was
} placed in the month with the greater number of days reaching $\geq 37^{\circ} \mathrm{C}$. 
Results from the analysis of covariance showed that regressions of urediniospores per lesion versus days of heat wave were $37^{\circ} \mathrm{C}$ area $=7,178.13-257.45 \times$ days of heat wave, AIC $=178.8$. The slope was not significant, $P=0.0844$ (Fig. 2C).

Effects of frequency of extreme temperature highs beginning after lesion formation. As expected, there were no reductions in numbers of lesions per square centimeter of leaf area because all potential lesions had formed by the time the heat treatments began (Fig. 4A). The cumulative number of urediniospores produced per plant for the entire experiment was reduced from $54 \times 10^{3}$ to $30 \times 10^{3}$ by three consecutive days with a temperature high of $35^{\circ} \mathrm{C}$ (Fig. 4B). Six and nine days with $35^{\circ} \mathrm{C}$ highs did not further decrease cumulative urediniospore production per plant (Fig. 4B). However, with each increase in consecutive days of extreme temperature highs, although not a reduction in urediniospores per plant, there was a significant reduction of urediniospore production per lesion with changes from zero to three and from three to six consecutive days with an extreme temperature high (Fig. 4C). Numbers of urediniospores collected on each collection date were significantly lower for three, six, or nine consecutive days with extreme temperature highs than with no extreme temperature highs (Fig. 5). Urediniospore production on consecutive collection dates did not recover by the end of the experiment (Fig. 5).

Results from the analysis of covariance showed that regressions of urediniospores per lesion versus days of heat wave were $35^{\circ} \mathrm{C}$ area $=10,000.68-743.49 \times$ days of heat wave, $\mathrm{AIC}=193.3$. The slope was significant at $P<0.0001$.
Frequency of extreme temperature highs in the field. Temperature highs of $35^{\circ} \mathrm{C}$ and above were frequent during June, July, and August, particularly in Alabama, Florida, Mississippi, and Georgia (Table 1). In Nebraska, although not common in June, high temperatures were common in July and August. Long strings of consecutive days in which temperatures reached $35^{\circ} \mathrm{C}$ and above occurred in Alabama in June 2009 and 2010, July 2006, and August 2007. For example, there was a string of 24 days in August 2007 in which the temperature reached or exceeded $35^{\circ} \mathrm{C}$. In Mississippi, 19 consecutive days reached or exceeded $35^{\circ} \mathrm{C}$ in June 2009 and 23 days in August 2007. Also in Mississippi, 14 and 17 consecutive days reached $\geq 35^{\circ} \mathrm{C}$ in August 2011. Georgia had a string of 19 days in June 2011, 13 in July 2006, 13 in July 2010, 14 in August 2007, and 13 in August 2011. Long strings of days in which temperatures reached or exceeded $35^{\circ} \mathrm{C}$ did not occur in Illinois, Iowa, or Nebraska. The years with the fewest days in the southeastern United States reaching $35^{\circ} \mathrm{C}$ or above during July and August were 2008 and 2009.

The frequencies of days reaching $37^{\circ} \mathrm{C}$ were much lower than $35^{\circ} \mathrm{C}$ and were highest in the southeastern states in June 2010 and 2011; July 2006, 2010, and 2011; and August 2006, 2007, 2010, and 2011 (Table 2).

Relationship of soybean rust field incidence to extreme temperature highs. As stated before, incidence for any given year was measured in terms of cumulative number of U.S. counties reporting the presence of soybean rust by 21 November (Table 3). There was a close negative relationship of incidence to number of days in which $35^{\circ} \mathrm{C}$ highs were reached. In 2005,135

TABLE 2. (continued from preceding page)

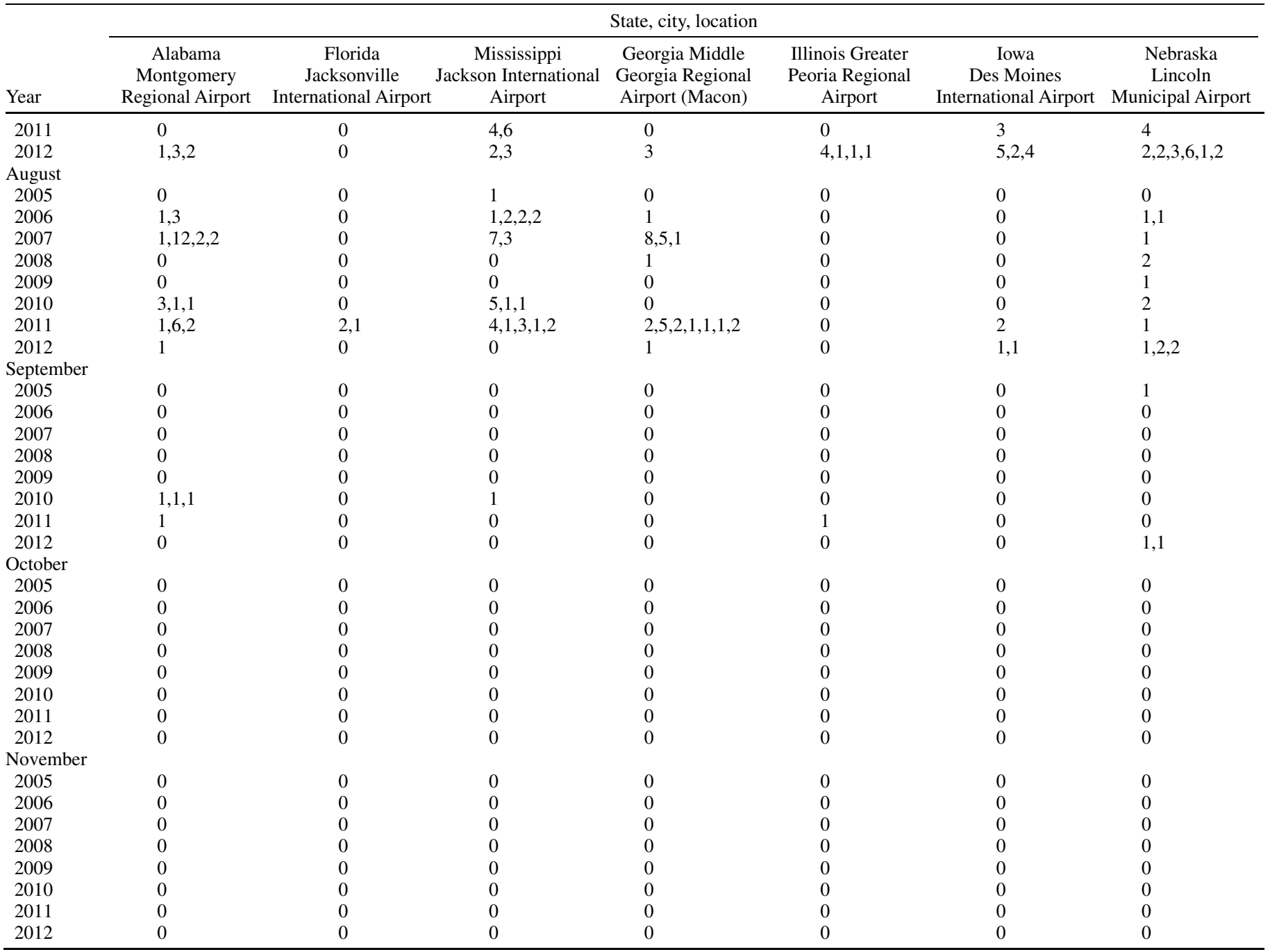


counties reported the presence of soybean rust. This relatively low incidence undoubtedly was due to the pathogen being not yet well established in North America.

From 2006 to 2012, the 3 years (2008, 2009, and 2012) with the fewest days with extreme temperature highs were the years in which the most counties reported soybean rust. Conversely, the 2 years with the most days with extreme temperature highs (2010 and 2011) were the years in which the fewest counties reported the presence of soybean rust.

Of particular interest was 2007, during which 26 counties in Texas reported the presence of soybean rust very early in the year. In spite of a very hot August in the southeastern United States, July lacked long stretches of extreme temperature highs, and the pathogen and disease were able to reach Illinois, Indiana, Iowa, and, eventually, Canada. We speculate that the spotty appearance

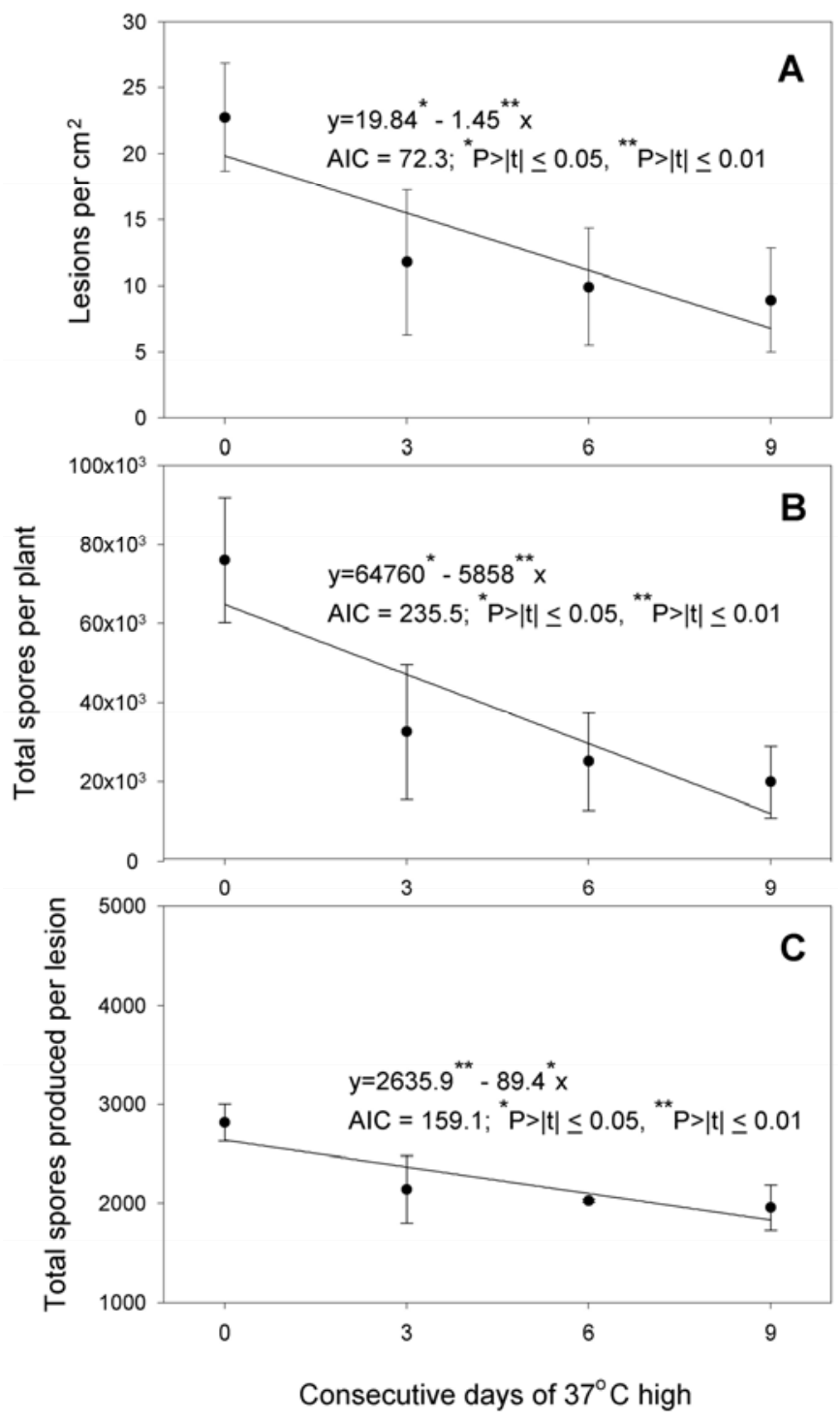

Fig. 2. Effects of $37^{\circ} \mathrm{C}$ extreme temperature highs initiated following inoculation and dew period. A, Linear regression showing decrease in numbers of lesions with increasing number of days with extreme temperature high. Note significant decrease in lesion numbers from 0 to 3 days with extreme temperature high. B, Total number of urediniospores collected from individual plants by 33 days after inoculation. Note significant reduction in urediniospores collected between 0 and 3 days of extreme temperature high. $\mathbf{C}$, Total number of urediniospores collected per lesion with $0,3,6$, or 9 days with extreme temperature high. Note that it is apparent that the reduction in urediniospores produced per plant was due to both fewer lesions and fewer urediniospores produced per lesion. Data points are means of three experiments; standard errors of the means are indicated. of the disease in the southeastern United States, in which many counties did not report rust, was due to poor temperature conditions during August.

\section{DISCUSSION}

Our previous study showed that a continuous period of extreme temperature highs (e.g., $33^{\circ} \mathrm{C}$ ) markedly reduced the rate of disease development. However, temperature patterns in nature never are constant. In order to further determine how extreme temperature highs affect soybean rust, we expanded our study to include frequency of these highs. Because the possible combinations of temperature highs and frequencies to test were limitless, it was necessary to make decisions as to what combinations to test. Following the first set of experiments conducted in this study, we slightly adjusted the temperature high to better reflect conditions in the field.

Three consecutive days in which the temperature high was $35^{\circ} \mathrm{C}$ reduced urediniospore production by $50 \%$. Because $35^{\circ} \mathrm{C}$ is reached or exceeded frequently during summer months in the southeastern United States, occurring on as many as 24 consecutive days (Table 1), and the reproductive rate of $P$. pachyrhizi is slow to recover once temperature extremes no longer exist, extreme temperature highs probably play a major role in limiting soybean rust development in nature. In our experiments, the temperature high lasted $1 \mathrm{~h}$ each day. However, in the field, extreme temperature highs may last longer and, therefore, sporulation may be reduced even further than what we experienced.

It is well documented that soybean rust severity generally does not increase appreciably in the southeastern United States until fall $(10,15,27,28)$. Indeed, since 2004 , when the disease first was discovered in the continental United States, soybean rust has never caused significant crop losses, probably due to late appearance or absence of disease in local areas. Some researchers have attributed the delay of soybean rust to low susceptibility of young plants to infection by $P$. pachyrhizi and believe that, as plants mature, they become more susceptible (28). For example, in northern Florida, Young et al. (28) reported that plants at reproductive growth stages $\mathrm{R}_{4}$ and $\mathrm{R}_{5}$ were more susceptible to soybean rust than younger plants, which is consistent with the observations of Tschanz (25) in Taiwan, who reported rapid increases in lesion numbers only after initiation of the $\mathrm{R}_{1}$ growth stage.

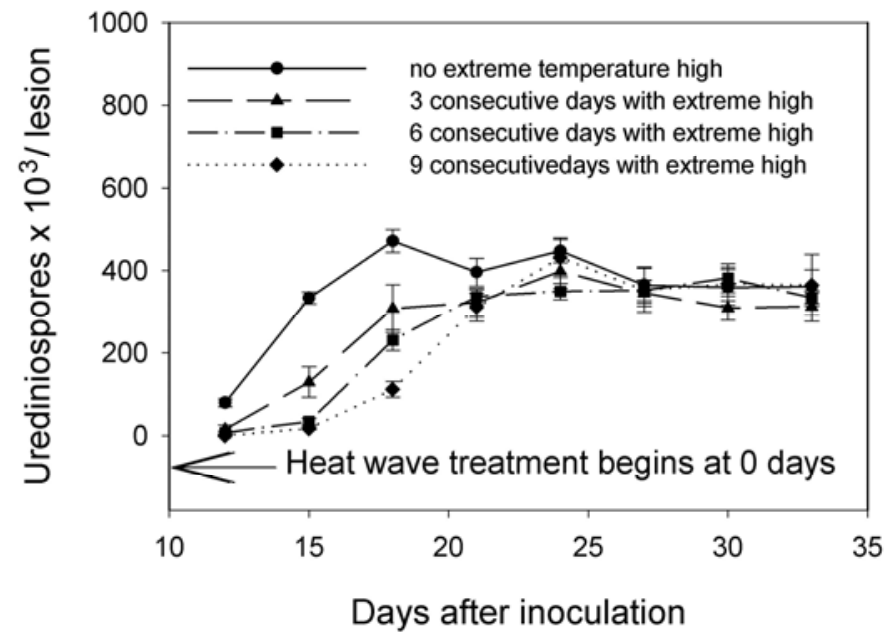

Fig. 3. Mean numbers of urediniospores collected at each of eight 3-day intervals in which inoculated plants were subjected to a $37^{\circ} \mathrm{C}$ temperature high for $1 \mathrm{~h}$ each day for $0,3,6$, or 9 consecutive days, beginning 15 days after inoculation. "Heat waves" refer to 1-h diurnal extreme temperature highs. Data points are the means for three sample plants in each of three experiments. Standard errors of the means are indicated. 
Contrary to the above observations, Melching et al. (18) reported that both young soybean plants and young leaves on plants were more susceptible than older plants and leaves. In Brazil, Moreira et al. (21) reported that they did not observe an increase in rust susceptibility as plants aged and, recently, we reported that, under controlled environmental conditions, plants gradually became less susceptible to $P$. pachyrhizi inoculations as plants aged (4). Relationship of plant age to susceptibility to soybean rust still is in question.

Li et al. (17) suggested a different possibility, other than plant age, for causing the observed delay in soybean rust development. They observed that, as urediniospores increasingly were exposed to sunlight, their viability and infection efficiency decreased. As day length decreased, disease development increased. They reasoned that the decreasing day length was responsible for the increasing level of disease, and believed that daytime tempera-

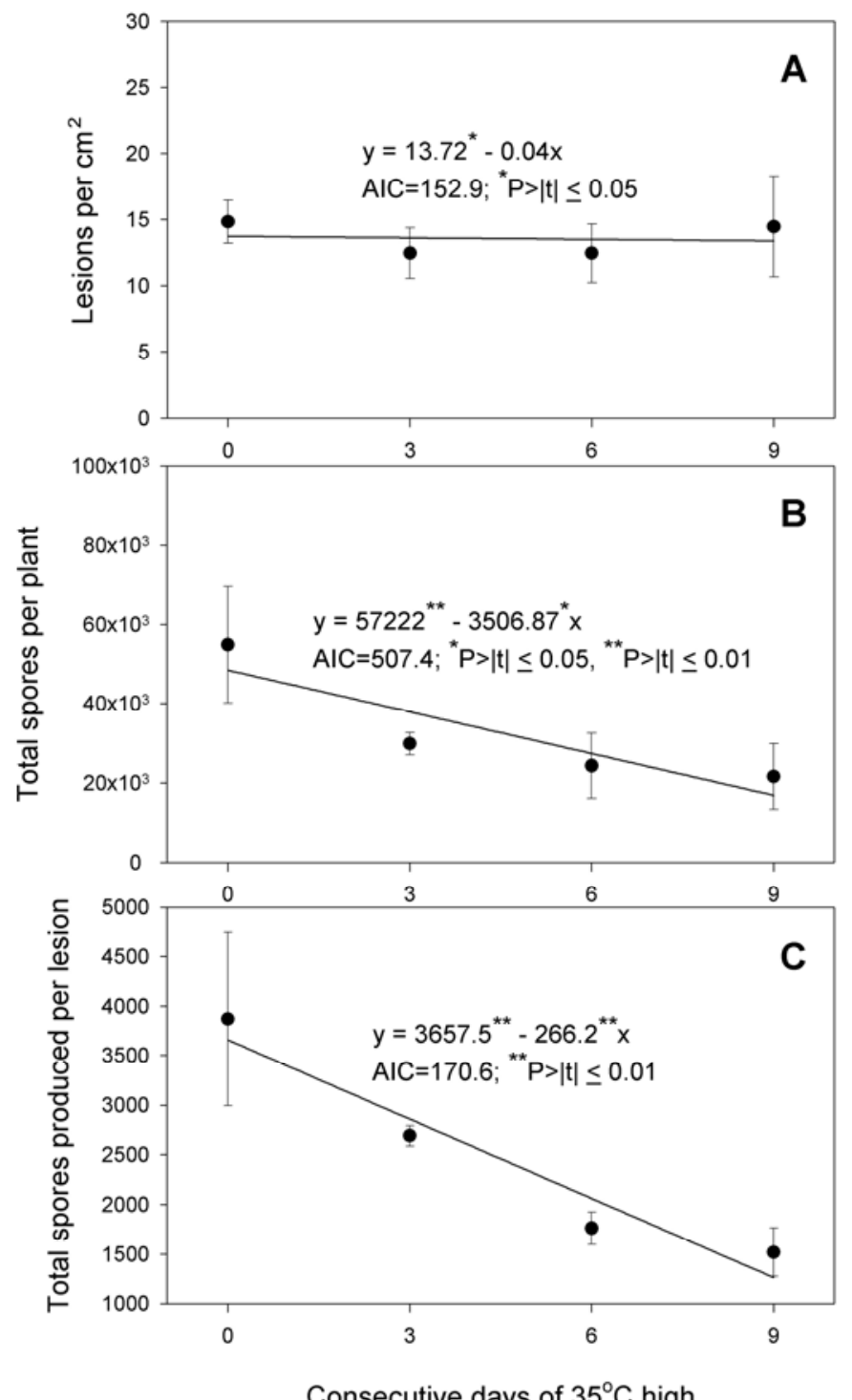

Fig. 4. Effects of $35^{\circ} \mathrm{C}$ extreme temperature highs initiated 15 days after inoculation, when lesions had formed. A, Effects of extreme temperature highs on numbers of lesions produced per unit leaf area. Note that there was no change in number of lesions over time. B, Total number of urediniospores produced per plant. Note the significant reduction in urediniospores produced from 0 to 3 days with extreme temperature high. C, Total number of urediniospores produced per lesion with $0,3,6$, or 9 days of extreme temperature high. Note that the decrease in number of urediniospores produced per plant was due entirely to fewer urediniospores produced per lesion over the 33 days following inoculation. Data points are the means of three experiments. Standard errors of the means are indicated. tures and opportunities for urediniospore dispersal could not account for delays in rust development prior to fall (17).

Our research has provided another, plausible explanation for the delay of soybean rust development. However, in spite of extreme temperature highs being frequent enough to account for the lack of significant disease loss in the field, the effects on disease spread were evident. During years in which daily temperatures commonly reached $35^{\circ} \mathrm{C}$, soybean rust spread was minimal, and few counties (e.g., $n=29$ and 14) and states (e.g., $n=7$ and 3) reported the disease. In years in which $35^{\circ} \mathrm{C}$ temperature highs were less common, many more counties (e.g., $n=364,382$, and 546) and states (e.g., $n=13,16$, and 16) reported rust.

At first, the year 2007 may appear as an anomaly. However, the untypical early appearance of rust in Texas in 2007 probably was responsible for the movement of the disease up through the Ohio River valley into midwestern states and, eventually, Canada prior to the hot month of August in the southern United States (Table1). The appearance of soybean rust in the midwestern and northern states was alarming because it showed that the disease could reach these areas. If inoculum were to reach these more northern areas early in the growing season, the favorable temperatures might allow substantial disease losses.

Ward et al. (27) recently reported that soybean rust infection can occur early in the cropping season and become latent. Our

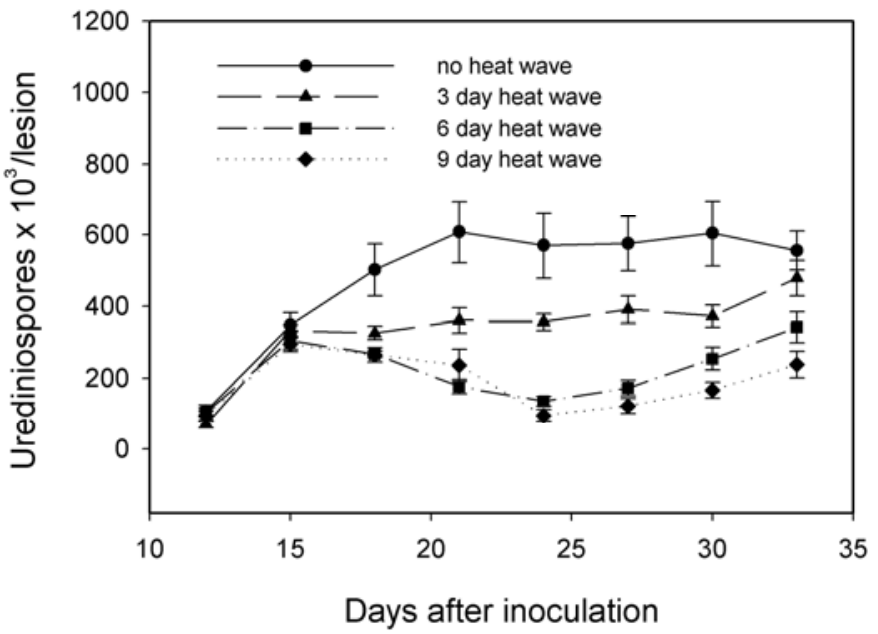

Fig. 5. Mean numbers of urediniospores collected at each of eight 3-day intervals in which inoculated plants were subjected to a $35^{\circ} \mathrm{C}$ temperature high for $1 \mathrm{~h}$ each day for $0,3,6$, or 9 consecutive days, beginning 15 days after inoculation. "Heat waves" refer to 1-h diurnal extreme temperature highs. Data points are the means for three sample plants in each of three experiments. Standard errors of the means are indicated.

TABLE 3. Number of counties and states with soybean rust and total number of days in which the temperature high reached or exceeded $35^{\circ} \mathrm{C}$

\begin{tabular}{lccc}
\hline Year $^{\mathrm{a}}$ & Days with highs $^{\mathrm{b}}$ & States with rust & Counties with rust \\
\hline 2006 & 147 & 15 & 268 \\
2007 & 131 & 19 & 289 \\
2008 & 68 & 16 & 382 \\
2009 & 86 & 16 & 546 \\
2010 & 182 & 7 & 29 \\
2011 & 204 & 3 & 14 \\
2012 & 120 & 13 & 364 \\
\hline
\end{tabular}

a Note that the 3 years $(2008,2009$, and 2012) with the fewest days with extreme temperature highs were the years with the most counties reporting soybean rust; conversely, the 2 years with the most days with extreme temperature highs (2010 and 2011) were the years with the fewest counties reporting soybean rust.

b Number of days with extreme temperature highs calculated by adding total cumulative number of days during June, July, and August for the states of Alabama, Florida, Georgia, and Mississippi in which the diurnal temperature high reached or exceeded $35^{\circ} \mathrm{C}$. 
data are consistent with their observations and suggest that the cause of the latency might be extreme temperature highs. When high temperature extremes become less frequent during fall months (Tables 1 and 2), fungal development resumes.

In spite of strong evidence that extreme temperature highs limit soybean rust development, other factors also play significant roles. Susceptible soybean and alternative host plants are required for inoculum build-up as the disease progressively moves from south to north during the cropping season. Air currents and winds are required for urediniospore transport. Without this transport into an area, disease will not occur if not already present. A lack of sufficient moisture on the surface of plants would restrict urediniospore germination and initiation of infection.

Disease incidence and temperature extremes in this study were examined from a large geographical perspective. It is reasonable to expect that disease incidence at the local level also was similarly affected by temperature. Data able to show this relationship may already exist, and analysis perhaps would lead to more precise soybean rust models to predict development of the disease.

The effects of environment on soybean rust development are complex, and environmental interactions likely exist. Although there can be several environmental factors which limit disease, with soybean rust, temperature is one of the most important. The delay or absence of soybean rust in the southeastern United States has implications far beyond local production. Because P. pachyrhizi cannot survive winters in midwestern and northern states, major soybean-producing regions of the country, development of the disease must first occur in the southeastern United States where the pathogen does survive (13). An understanding of the effects of temperature on soybean rust development takes on great importance for the entire country and could lead to improved prediction models, thus reducing or possibly eliminating fungicide use.

\section{ACKNOWLEDGMENTS}

Mention of trade names or commercial products in this publication is solely for the purpose of providing specific information and does not imply recommendation or endorsement by the United States Department of Agriculture (USDA). The USDA prohibits discrimination in all its programs and activities on the basis of race, color, national origin, age, disability, and where applicable, sex, marital status, familial status, parental status, religion, sexual orientation, genetic information, political beliefs, reprisal, or because all or a part of an individual's income is derived from any public assistance program. (Not all prohibited bases apply to all programs.) Persons with disabilities who require alternative means for communication of program information (Braille, large print, audiotape, etc.) should contact USDA's TARGET Center at (202) 7202600 (voice and TDD). To file a complaint of discrimination write to USDA, Director, Office of Civil Rights, 1400 Independence Avenue, SW, Washington, DC 20250-9410 or call (800) 795-3272 (voice) or (202) 7206382 (TDD). USDA is an equal opportunity provider and employer.

\section{LITERATURE CITED}

1. Akaike, H. 1974. A new look at the statistical model identification. IEEE Trans. Automatic Control 19:716-723.

2. Bonde, M. R., Berner, D. K., and Nester, S. E. 2009. Effects of post-dew period temperature and relative humidity on Phakopsora pachyrhizi urediniospore production. In: Proc. Natl. Soybean Rust Symp. New Orleans.

3. Bonde, M. R., Nester, S. E., Austin, C. N., Stone, C. L., Frederick, R. D., Hartman, G. L., and Miles, M. R. 2006. Evaluation of virulence of Phakopsora pachyrhizi and P. meibomiae isolates. Plant Dis. 90:708-716.

4. Bonde, M. R., Nester, S. E., and Berner, D. K. 2012. Effects of soybean leaf and plant age on susceptibility to initiation of infection by Phakopsora pachyrhizi. Plant Health Progress. Online publication. doi:10.1094/ PHP-2012-0227-01-RS

5. Bonde, M. R., Nester, S. E., and Berner, D. K. 2012. Effects of daily temperature highs on development of Phakopsora pachyrhizi on soybean. Phytopathology 102:761-768.

6. Bonde, M. R., Nester, S. E., Berner, D. K., Frederick, R. D., Moore, W. F., and Little, S. 2008. Comparative susceptibilities of legume species to infection by Phakopsora pachyrhizi. Plant Dis. 92:30-36.

7. Bonde, M. R., Nester, S. E., Moore, W. F., and Allen, T. W. 2009. Comparative susceptibility of kudzu accessions from southeastern United States to infection by Phakopsora pachyrhizi. Plant Dis. 93:593-598.

8. Bromfield, K. R. 1984. Soybean rust. Monogr. No. 11. American Phytopathological Society, St. Paul, MN.

9. Del Ponte, E. M., Godoy, C. V., Li, X., and Yang, X. B. 2006. Predicting severity of Asian soybean rust epidemics with empirical rainfall models. Phytopathology 96:797-803.

10. Dias, A. P. S., Li, X., Harmon, P. F., Harmon, C. L., and Yang, X. B. 2011. Effects of shade intensity and duration on Asian soybean rust caused by Phakopsora pachyrhizi. Plant Dis. 95:485-489.

11. Giesler, L. J. 2006. Overview of soybean rust in North America in 2006. In: 2nd Natl. Soybean Rust Symp. American Phytopathological Society, St. Louis. http://www.plantmanagementnetwork.org/

12. Hennings, P. 1903. Some new Japanese Uredinales. IV. Hedwigia Suppl. 42:107-108. (In German)

13. Isard, S. A., Barnes, C. W., Hambleton, S., Ariatti, A., Russo, J. M., Tenuta, A., Gay, D. A., and Szabo, L. J. 2011. Predicting soybean rust incursions into the North American continental interior using crop monitoring, spore trapping, and aerobiological modeling. Plant Dis. 95:1346-1357.

14. Isard, S. A., Dufault, N. S., Miles, M. R., Hartman, G. L., Russo, J. M., DeWolf, E. D., and Morel, W. 2006. The effect of solar irradiance on the mortality of Phakopsora pachyrhizi urediniospores. Plant Dis. 90:941945.

15. Isard, S. A., Russo, J. M., and Ariatti, A. 2007. The integrated aerobiology modeling system applied to the spread of soybean rust into the Ohio River valley during September 2006. Aerobiologia 12:271-282.

16. Levy, C. 2005. Epidemiology and chemical control of soybean rust in southern Africa. Plant Dis. 89:669-674.

17. Li, X., Mo, J., Guo, T., and Yang, X. 2010. Effects of light on urediniospore germination, appressorium formation and infection efficiency of Phakopsora pachyrhizi, causal agent of soybean rust. Can. J. Plant Pathol. 32:153-161.

18. Melching, J. S., Dowler, W. M., Koogle, D. L., and Royer, M. H. 1988. Effect of plant and leaf age on susceptibility of soybean to soybean rust. Can. J. Plant Pathol. 10:30-35.

19. Melching, J. S., Dowler. W. M., Koogle, D. L., and Royer, M. H. 1989. Effects of duration, frequency, and temperature of leaf wetness periods on soybean rust. Plant Dis. 73:117-122.

20. Millett, B. P., Mollov, D. S., Iorizzo, M., Carputo, D., and Bradeen, J. M. 2009. Changes in disease resistance phenotypes associated with plant physiological age are not caused by variation in $R$ gene transcript abundance. Mol. Plant-Microbe Interact. 22:362-368.

21. Moreira, E. N., Rodrigues, R. A., Do Vale, F. X. R., and Costa, L. C. 2009. The occurrence of soybean rust depends on crop phenologic stages? In: Online 2009 Natl. Soybean Rust Symp. New Orleans. Plant Management Network, St. Paul, MN.

22. Morel, W., and Yorinori, J. T. 2002. Situacion de la roja de la soja en el Paraguay. Bol de Diulgacion No. 44. Ministerio de Agricultura y Granaderia, Centro Regional de Invertigacion Agricola, Capitan Miranda, Paraguay.

23. Rossi, R. L. 2003. First report of Phakopsora pachyrhizi, the causal organism of soybean rust in the Province of Misiones, Argentina. Plant Dis. 87:102.

24. Schneider, R. W., Hollier, C. A., Whitman, H. K., Palm, M. E., McKemy, J. M., Hernandez, J. R., Levy, L., and DeVries-Patterson, R. 2005. First report of soybean rust caused by Phakopsora pachyrhizi in the continental United States. Plant Dis. 89:774.

25. Tschanz, A. 1982. Final Report: Soybean Rust Epidemiology. USDA Contract No. 12-14-1001-1227, March 3, 1978-March 2, 1982. Asian Vegetable Research and Development Center. Shanhua, Taiwan, Republic of China.

26. Van den Berg, F., and van den Bosh, F. 2007. The elasticity of the epidemic growth rate to observed weather patterns with an application to yellow rust. Phytopathology 97:1512-1518.

27. Ward, N. A., Schneider, R. W., and Robertson, C. 2012. Documentation of an extended latent infection period by Phakopsora pachyrhizi, the soybean rust pathogen. Plant Health Progress. Online publication. doi: 10.1094/PHP-2012-0321-01-RS

28. Young, H. M., Marois, J. J., Wright, D. L., Narvaez, D. F., and O'Brien, G. K. 2011. Epidemiology of soybean rust in soybean sentinel plots in Florida. Plant Dis. 95:744-750. 